\title{
PENERAPAN METODE PENYUSUTAN ASET TETAP ( Studi kasus pada PT CHANDRA SAKTI UTAMA LEASING JAKARTA )
}

\author{
Setiadi \\ Program Studi Akuntansi - Fakultas Ekonomi \\ Universitas Dirgantara Marsekal Suryadarma \\ tedi.hartoko@gmail.com
}

\begin{abstract}
Abstrak
Aset tetap merupakan komponen yang sangat penting bagi perusahaan untuk kegiatan operasionalnya. Metode penulisan dengan kajian pustaka dan kajian lapangan. Aset tetap merupakan salah satu komponen dalam neraca yang sangat penting bagi perusahaan untuk pelaksanaan kegiatan operasional dan sebagai penunjang tercapainya tujuan didirikan perusahaan tersebut. Penyusutan dikenal juga dengan istilah depresiasi yaitu pengalokasian aset tetap yang disebabkan adanya penurunan nilai dari aset tetap tersebut. Perhitungan penyusutan aset tetap pada PT Chandra Sakti Utama Leasing menggunakan metode garis lurus.
\end{abstract}

Kata Kunci : Aset Tetap, Garis Lurus, Nilai Aset.

\section{PENDAHULUAN}

Aset tetap merupakan komponen yang sangat penting bagi perusahaan untuk kegiatan operasionalnya. Aset tetap tersebut merupakan salah satu komponen dalam neraca, sehingga ketelitian dalam pengolahan aset tetap sangat berpengaruh terhadap kewajaran penilaiannya dalam laporan keuangan.

Aset tetap biasanya memiliki masa pemakaian lebih dari satu tahun, sehingga diharapkan dapat memberikan manfaat bagi perusahaan dalam jangka waktu yang relatif lama. Namun, manfaat yang diberikan aset tetap umumnya semakin lama semakin menurun manfaatnya secara terus menerus, dan menyebabkan terjadi penyusutan (depreciation).

Seiring dengan berlalunya waktu, aset tetap akan mengalami penyusutan (kecuali tanah). Faktor yang mempengaruhi menurun kemampuan suatu aset tetap untuk memberikan jasa/manfaaat yaitu : Secara fisik, disebabkan oleh pemakaian karena penggunaan yang berlebihan dan secara fungsional, disebabkan oleh ketidakcukupan kapasitas yang tersedia dengan yang diminta (misal kemajuan teknologi). Sehingga penurunan kemampuan aset tetap tersebut dapat dialokasikan sebagai biaya.

Biaya penyusutan suatu aset tetap akan mempengaruhi laporan keuangan dan hasil kinerja perusahaan pada suatu periode akuntansi. Sehingga dalam melakukan penyusutan aset tetapnya, PT Chandra Sakti Utama Leasing menggunakan metode garis lurus (straight line method), karena dalam metode ini seluruh biaya aset yang sama dialokasikan ke setiap periode akuntansi selama masa manfaat aset tersebut. 
Berdasarkan uraian diatas maka metode penyusutan aset tetap sangat penting diterapkan sehingga membuat judul: "Penerapan Metode Penyusutan Aset Tetap (Studi kasus pada PT Chandra Sakti Utama Leasing Jakarta ) ”

\section{METODOLOGI PENULISAN}

Dalam pembuatan penelitian ini, penulis membutuhkan data-data yang berhubungan dengan kajian penulis, yaitu bersumber dari :

\section{Studi Pustaka (Library Research)}

Yaitu pengambilan data yang dilakukan dengan membaca dan mempelajari buku-buku referensi yang berkaitan dengan topik dalam penulisan ini. Dengan tujuan untuk mendapatkan pengetahuan teoritis dengan kebenaran dan keakuratan.

\section{Studi Lapangan (Field Research)}

Yaitu memperoleh data dengan cara observasi langsung ke tempat yang menjadi objek penulisan sekaligus tempat penulis bekerja pada PT Chandra Sakti Utama Leasing di Jakarta Selatan, penulis juga melakukan wawancara kepada pihak-pihak yang terkait dengan materi penulisan.

\section{TINJAUAN PUSTAKA}

\section{Pengertian Penyusutan}

Menurut PSAK No.16 (2011:13 paragraf 06 ) Penyusutan adalah "Alokasi sistematis jumlah yang dapat disusutkan dari suatu aset selama umur manfaatnya."
Menurut Rudianto (2012:260) dalam bukunya "Pengantar Akuntansi" penyusutan adalah "Pengalokasian harga perolehan aset tetap menjadi beban ke dalam periode akuntansi yang menikmati manfaat dari aset tetap tersebut."

\section{Pengertian Aset Tetap}

Suatu entitas memerlukan sebuah laporan keuangan untuk mengikhtisarkan posisi keuangannya. Neraca adalah salah satu laporan keuangan dasar yang biasanya disusun oleh organisasi yang mencari laba, untuk digunakan oleh investor, kreditor, dan pengambilan keputusan eksternal yang lainnya. Neraca menggambarkan posisi keuangan dengan komponen aktiva (harta/asset) dan pasiva (kewajiban dan modal/payable and equity). Aset terdiri dari aset lancar (current asset), aset tetap (fixed asset) dan aset lain-lain (other asset).

Aset tetap merupakan salah satu komponen dalam neraca yang sangat penting bagi perusahaan untuk pelaksanaan kegiatan operasional dan sebagai penunjang tercapainya tujuan didirikan perusahaan tersebut. Oleh karena itu, ketelitian dan kecermatan dalam pengolahan aset tetap sangat berpengaruh terhadap kewajaran penilaian dalam laporan keuangan. Sebelum membahas aktiva tetap lebih mendalam, terlebih dahulu penulis akan memaparkan tentang definisi-definisi aktiva tetap. Berikut ini definisi-definisi mengenai aset tetap dari berbagai sumber : 
Menurut PSAK No.16 (2011:12 paragraf 06) aset tetap adalah "aset yang berwujud dimiliki untuk digunakan dalam produksi atau penyediaan barang atau jasa untuk direntalkan kepada pihak lain, atau untuk tujuan administratif dan diharapkan untuk digunakan selama lebih dari satu periode."

Menurut Rudianto (2012:256) dalam bukunya "Pengantar Akuntansi" aset tetap adalah "Barang berwujud milik perusahaan yang sifatnya relatif permanen dan digunakan dalam kegiatan normal perusahaan, bukan untuk diperjualbelikan."

Menurut Akifa P.Nayla (2014:12) dalam bukunya "Akuntansi Jasa, Dagang, dan Perbakan" aset tetap adalah "Jenis aset berwujud yang dapat diperoleh dalam bentuk siap pakai atau dibangun terlebih dahulu sehingga dapat dimanfaatkan atau difungsikan untuk kegiatan operasional perusahaan."

Menurut Al. Haryono Jusup (2014:133) dalam bukunya "Dasar-dasar Akuntansi Jilid 2" aset tetap adalah : "Sumber daya yang memiliki empat karakteristik yaitu berwujud atau memiliki ujud (bentuk atau ukuran tertentu), digunakan dalam operasi perusahaan, mempunyai masa manfaat jangka panjang dan tidak dimaksudkan untuk diperjualbelikan.”

\section{Pengelompokkan Aset Tetap}

Menurut Muhammad Nuh \& Hamizar (2011:196) harta tetap yang dimiliki perusahaan dapat dikelompokkan sebagai berikut :

a. Dari sisi wujud aset tetap :

Tangible asset adalah harta tetap yang memiliki wujud kebendaan yang nyata seperti : Tanah, mesin, bangunan, peralatan, kendaraan dan lain-lain.

Intangible asset adalah harta yang tidak memiliki fisik nyata, tapi memiliki nilai ekonomis yang tinggi seperti : Hak guna bangunan (HGB), hak guna usaha (HGU), hak Patent, Hak Cipta, Franchise, Organnization Cost, Hak penguasahaan Hutan (HPH) dan lain-lain.

b. Dari sudut disusutkan atau tidak,harta tetap dapat dibagi menjadi :

Harta tetap yang disusutkan (Depreciated Plant Asset) yang termasuk kelompok ini adalah peralatan, gedung, kendaraan, mesin dll.

Harta tetap yang tidak disusutkan (Undepreciated Plant Asset) yang termasuk kelompok ini adalah tanah.

\section{Harga Perolehan Aset Tetap}

Harga perolehan aset tetap adalah harga yang akan dipakai sebagai dasar pelaporan nilai harta tetap dalam neraca perusahaan dan akan dijadikan dasar perhitungan penyusutan harta tetap yang bersangkutan. Niai ini terdiri dari dari harga beli harta tetap yang bersangkutan ditambah dengan biaya-biaya yang dikeluarkan dan diperhitungkan sampai harta tetap yang bersangkutan dapat dipergunakan dan dimanfatkan. PSAK No. 16 butir 14 
menyatakan secara lengkap sebagai berikut : biaya perolehan (Cost) suatu aset tetap adalah terdiri dari harga belinya, termasuk bea impor dan PPN / PPN BM dan biaya lain yang dapat distribusikan secara langsung dalam membawa aset tetap yang bersangkutan dapat bekerja dan/ dipergunakan.

Biaya-biaya yang dimaksudkan adalah:
a. Biaya persiapan tempat
b. Biaya pengiriman awal
c. Biaya pemasangan
d. Biaya konsultan

Untuk menentukan berapa besarnya nilai harga perolehan suatu aset tetap, berlaku prinsip yang menyatakan bahwa semua pengeluaran yang terjadi sejak pembelian sampai aset tersebut siap digunakan harus diperhitungkan kedalam harga perolehan harta tetap (Kapitalisasi). Karena aset tetap itu mempunyai masalah- masalah yang berbeda, maka harga perolehannyapun akan berbeda. Dibawah ini diberikan cara perhitungan harga perolehan dari berbagai aset tetap sebagai berikut :

a. Tanah

Tanah yang dimiliki perusahaan untuk tempat gedung berdiri merupakan aset tetap perusahaan dan harus dicatat dalam rekening tanah. Apabila tanah itu tidak digunakan sebagai tempat usaha perusahaan, maka tanah yang bersangkutan dicatat kedalam investasi jangka panjang. Harga perolehan tanah terdiri dari : harga beli, komisi pembelian, bea balik nama, biaya penelitian tanah, pajak - pajak yang timbul akibat pengalihan hak kepemilikan yang dibayar oleh sipembeli, biaya perobohan bangunan, biaya peralatan tanah, biaya lain yang dikeluarkan untuk memperbaiki keadaan tanah.

b. Bangunan

Gedung yang didapatan dari hasil pembelian, harga perolehannya harus meliputi : harga beli bangunan, biaya perbaikan sebelum gedung itu dipakai, komisi pembelian, bea balik nama, pajak yang tanggungan sipembeli. Bila gedung ini dibangun sendiri, maka harga perolehannya terdiri dari : biaya pembuatan gedung yang terdiri dari biaya bahan, biaya tenaga kerja dan biaya lain-lain yang dibebankan kepada nilai gedung. Biaya perencanaan, gambar dan lain-lain, biaya pengurusan izin mendirikan bangunan, pajak-pajak selama bangunan, pajak-pajak selama pembangunan gedung, bunga selama pembangunan gedung, asuransi selama pembangunan gedung.

c. Mesin dan alat alat

Harga perolehan mesin dan alat-alat adalah : harga beli, pajak yang menjadi beban sipembeli, biaya angkut, asuransi dalam perjalanan, biaya pemasangan, biaya uji coba.

d. Perabot dan alat-alat kantor

Aset tetap yang masuk kedalam kelompok ini adalah : kursi, meja, lemari, mesin ketik, telepon, faximile, komputer, ac, dll. Yang menjadi harga perolehan dari aset tetap ini adalah : harga beli, biaya angkut, pajak dan lain yang dikeluarkan terhadap aset tetap yang bersangkutan sebelum digunakan. 


\section{e. Kendaraan}

Kendaraan adalah alat pengangkutan yang dimiliki dan dikuasai oleh perusahaan baik yang beroda dua maupun yang beroda lebih dari dua. Harga perolehan kendaraan terdiri dari harga beli dari kendaraan, bea balik nama, biaya angkut, pajak pertambahan nilai dan biaya-biaya lain yang dikeluarkan sebelum aset tetap yang bersangkutan dapat digunakan.

Menurut PSAK No.16 (2011:12 paragraf 06) Harga Perolehan adalah "Jumlah kas atau setara kas yang dibayarkan atau nilai wajar dari imbalan lain yang diserahkan untuk memperoleh suatu aset pada saat perolehan."

\section{Faktor-Faktor Penyusutan}

Menurut Rudianto (2012:260) dalam bukunya "Pengantar Akuntansi" ada tiga faktor yang perlu dipertimbangkan dalam menentukan beban penyusutan setiap periode. faktor - faktor itu ialah :

a. Harga Perolehan

Yaitu keseluruhan uang yang dikeluarkan untuk memperoleh suatu aset tetap sampai siap digunakan oleh perusahaan. b. Nilai Sisa (residu)

Yaitu taksiran harga jual aset tetap pada akhir masa manfaatnya. Setiap perusahaan akan memiliki taksiran yang berbeda satu dengan lainnya atas suatu jenis aset tetap yang sama. Jumlah taksiran nilai residu juga akan sangat dipengaruhi oleh umur ekonomisnya, inflasi, nilai tukar mata uang, bidang usaha, dan sebaginya. c. Taksiran Umur (masa manfaat)

Yaitu taksiran masa manfaat dari aset tetap. Masa manfaat adalah taksiran umur ekonomis dari aset tetap, bukan umur teknis. Taksiran masa manfaat dapat dinyatakan dalam satuan periode waktu, satuan hasil, atau satuan jam kerja.

\section{Metode Penyusutan Aset Tetap}

Menurut Elvy Maria Manurung (2011:93) dalam bukunya "Akuntansi Dasar" untuk mengalokasikan harga perolehan suatu aset tetap ke periode yang menikmati aset tetap tersebut bukan hanya dapat digunakan satu metode saja, tetapi ada beberapa metode yang dapat digunakan, seperti metode garis lurus (straight line method), metode saldo menurun (declining balance method), metode unit produksi (unit of production method), yaitu :

a. Metode Garis Lurus (Straight Line Method)

Ini merupakan metode penyusutan yang membagi harga perolehan asset (sesudah dikurangi nilai sisa, jika ada) dengan umur ekonomisnya, yang sama rata setiap tahun/periode. Rumusnya adalah :

Penyusutan $=$ Harga Perolehan - Nilai Sisa Taksiran Umur Ekonomis Aset

Metode perhitungan penyusutan garis lurus akan menghasilkan beban penyusutan aset tetap yang sama dari tahun ke tahun. Metode ini juga dapat menghasilkan beban penyusutan berupa suatu persentase dari harga perolehan aset tetap. 
b. Metode Saldo Menurun (Double Declining Method)

Penyusutan dengan menggunakan metode ini mengasumsikan bahwa nilai yang disusutkan pada tahun-tahun awal (pertama) akan memiliki nilai yang lebih besar, karena estimasi umur ekonomis lebih besar. Rumusnya adalah :

Penyusutan $(T h n)=$ Sisa Nilai Buku $\times$ Tarif Penyusutan

Tarif penyusutan dipercepat (accelerated depreciation rate) yang digunakan dalam metode saldo menurun (double declining method) adalah 200\% dari tarif yang digunakan dalam metode garis lurus (straight line). Jadi, jika aset tetap memiliki umur ekonomis 5 tahun, berarti tarif penyusutan metode garis lurus adalah $20 \%$ (100\% : 5 tahun), sehingga tarif untuk metode saldo menurun (double the declining balance method) adalah 40\% (2 x 20\%).

c. Metode Unit Produksi (Unit of Production Method)

Metode ini menggunakan tarif per unit produk, atau tarif per jam kerja mesin, untuk menghitung penyusutannya. Karena itu, aset tetap hendak disusutkan harus terlebih dahulu diestimasi jumlah unit total yang akan diproduksi, atau jumlah jam kerja mesin total sampai mesin berhenti beroperasi. Rumusnya:

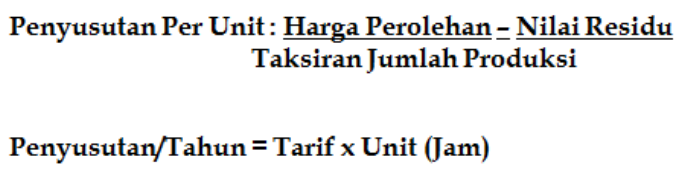

Penyusutan $/$ Tahun $=$ Tarif $\times$ Unit $($ Jam $)$

Pencatatan Beban Penyusutan Aset Tetap

\section{Pencatatan Beban Penyusutan Aset Tetap}

Pengakuan atas penggunaan manfaat potensial dari suatu aset. Sifat penyusutan secara konsep tidak berbeda dengan beban yang mengakui pemanfaatan atas premi asuransi ataupun sewa yang dibayar dimuka selama periode berjalan. Penyusutan merupakan beban yang tidak memerlukan pengeluaran uang kas. Alokasi harga perolehan aset tetap dilakukan dengan cara mendebet akun beban penyusutan dan mengkredit akun akumulasi penyusutan. Akun penyusutan akan tampak dalam laporan laba rugi, sedangkan akun akumulasi akan tampak terlihat dalam neraca. Contohnya sebagai berikut :

a. Pada Saat Pencatatan Pembelian Aset Secara Kredit

$$
\begin{array}{ll}
\text { (Dr) Vehicle } & \text { Rp } x x x x \\
\text { (Cr) Account Payable } & \text { Rp xxxx }
\end{array}
$$

b. Pada Saat Pencatatan Pembayaran Hutang

$$
\begin{array}{lll}
\text { (Dr) Account Payable } & \text { Rp } x x x x & \\
\text { (Cr) Cash/Cash in Bank } & & R p x \times x x
\end{array}
$$

c. Pada Saat Pencatatan Penyusutan Aset Tetap

$$
\begin{array}{lll}
\text { (Dr) Depr. Vehicle Exp } & \text { Rp xxxx } & \\
\text { (Cr) Acc. Depr Vehicle } & & \text { Rp } x x x x
\end{array}
$$

\section{Pelaporan Aset Tetap Dalam Neraca \\ Pada umumnya perusahaan menggabungkan aset-aset tetap dengan sumber-sumber alam dalam satu kelompok}


di neraca (laporan posisi keuangan), sedangkan aset tidak berwujud dilaporkan secara terpisah dalam kelompok tersendiri. Kelompok akun pertama seperti tanah, bangunan, dan peralatan, serta akumulasi depresiasi, diungkapkan baik dengan di neraca mau pun dalam catatan atas laporan keuangan. Berikut contoh pelaporan aset dalam neraca :

\begin{tabular}{|c|c|}
\hline \multicolumn{2}{|c|}{ PT NINDA SEJAHTERA } \\
\hline \multicolumn{2}{|c|}{ Neraca } \\
\hline \multicolumn{2}{|c|}{31 Desember 2012} \\
\hline \multicolumn{2}{|l|}{ Aset Tetap Berwujud } \\
\hline Tanah & $\operatorname{Rp} x x x x$ \\
\hline Bangunan & $\operatorname{Rp} x x x x$ \\
\hline \multirow[t]{2}{*}{ Mesin dan Peralatan } & $\underline{\operatorname{Rp} x x x x}$ \\
\hline & $\operatorname{Rp} x x x x$ \\
\hline Akumulasi Depresiasi & $\underline{(\operatorname{Rp} x x x x)}$ \\
\hline Aset Tetap Berwujud - Neto & $\operatorname{Rp} x x x x$ \\
\hline \multicolumn{2}{|l|}{ Aset Tak Berwujud } \\
\hline Goodwill & $\operatorname{Rp} x x x x$ \\
\hline \multicolumn{2}{|c|}{ Hak Merek dan aset tak berwujud lainnya - Neto $\operatorname{Rp} x x x x$} \\
\hline Aset Tak Berwujud - Neto & $R p x x x x$ \\
\hline
\end{tabular}

\section{PEMBAHASAN}

Cara menghitung Harga Perolehan Aset Tetap PT Chandra Sakti Utama Leasing.

Harga Perolehan yaitu keseluruhan uang yang dikeluarkan untuk memperoleh suatu aset tetap sampai siap digunakan oleh perusahaan. Harga perolehan aset tetap berdasarkan pembelian yang dilakukan oleh bagian GA (General Affair) atas permintaan divisi yang memiliki suatu kepentingan terhadap aset tersebut atau untuk menunjang kinerja karyawan. Sebagai contoh pembelian laptop, computer PC, filling cabinet, kendaraan dan lain-lain. Harga minimum dijadikan sebagai harga perolehan aset tetap adalah Rp 2.500.000,-
Contoh Perhitungan Harga Perolehan Kendaraan PT Chandra Sakti Utama Leasing sebagai berikut :

Pada tanggal 26 November 2014 PT Chandra Sakti Utama Leasing membuat purchase order dengan No : 281/POGA/CSUL/XI/14 dan No : 280/POGA/CSUL/XI/14 untuk membeli 2 unit mobil TOYOTA Rush S A/T TRD pada PT Astra International Tbk dengan detail per mobil sebagai berikut :

Berdasarkan purchase order dari PT Astra International Tbk membuat purchase order dengan No : 281/PO-GA/CSUL/XI/14 :

$\begin{array}{ll}\text { Harga Beli Kendaraan } & : \text { Rp 189.272.728,- } \\ \text { Discount } & : \underline{(R p ~ 22.727 .273,-) ~} \\ \text { Dasar Pengenaan Pajak } & : \operatorname{Rp~166.545.455,-~} \\ \text { Pajak Pertambahan Nilai } & : \operatorname{Rp} 16.654 .545,- \\ \text { Biaya Adm dan Pengurusan Surat Kendaraan } & : \underline{\operatorname{Rp} 31.250 .000,-} \\ \text { Total (IDR) } & : \operatorname{Rp} 214.450 .000,-\end{array}$

Aset tetap akan mengalami penyusutan dari satu periode ke periode berikutnya, jadi nilai kegunaan aset tetap akan terus berkurang pada setiap periodenya. Dalam suatu periode tertentu apabila sudah digunakan atau dimanfaatkan maka nilai aset tetap akan mengalami penurunan.

Penyusutan aset tetap terjadi karena berkurangnya nilai kegunaan aset tetap yang disebabkan karena adanya pemakaian aset tetap tersebut. Penyusutan dikenal juga dengan istilah depresiasi yaitu pengalokasian aset tetap yang disebabkan adanya penurunan nilai dari aset tetap 
tersebut. Penyusutan yang digunakan oleh PT Chandra Sakti Utama Leasing menggunakan metode penyusutan Straight Line Method (Metode Garis Lurus) untuk semua aset yang digunakan dalam operasional perusahaan. Penggunaan metode ini digunakan bila jumlah penyusutan yang dibebankan untuk setiap periode adalah sama.

\section{Metode Penyusutan Dan Perhitungan} Aset Tetap yang dilakukan oleh PT Chandra Sakti Utama Leasing.

Metode penyusutan yang dilakukan oleh PT Chandra Sakti Utama Leasing aset tetap tersebut digunakan untuk kegiatan operasional perusahaan dalam jangka panjang maupun dalam kegiatan normal perusahaan. PT Chandra Sakti Utama Leasing menggunakan metode penyusutan Straight Line Method (Metode Garis Lurus) untuk semua aset yang digunakan dalam operasional perusahaan. Penggunaan metode ini digunakan bila jumlah penyusutan yang dibebankan untuk setiap periode adalah sama. Dalam metode garis lurus penyusutan berarti beban penyusutan dibebankan oleh perusahaan secara merata ke seluruh umur taksiran aset tetap tersebut.

PT Chandra Sakti Utama Leasing membeli sebuah mobil Toyota TOYOTA Rush S A/T TRD sebanyak 2 unit pada tanggal 07 Januari 2015 dengan harga per unit yaitu Rp 214.450.000,- dengan umur ekonomis 8 tahun dan tanpa nilai residu (0), maka beban penyusutannya dengan metode garis lurus yaitu :

\section{Penyusutan $=\underline{\text { Harga Perolehan }}=\underline{\text { Nilai Sisa }}$}

Taksiran Umur Ekonomis Aset

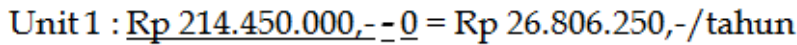

8 Tahun / 96 bulan

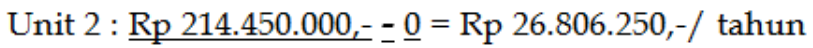
8 Tahun / 96 bulan

Maka beban penyusutan mobil Toyota TOYOTA Rush S A/T TRD pada PT Chandra Sakti Utama Leasing adalah $\mathrm{Rp}$ 26.806.250,--

Berikut adalah tabel penyusutan aset tetap mobil Toyota TOYOTA Rush S A/T TRD pada PT Chandra Sakti Utama Leasing.

Penyusutan Toyota TOYOTA Rush S A/T TRD :

\begin{tabular}{|c|c|c|c|c|}
\hline TH & HP & DEPRE & $\begin{array}{c}\text { ACC. } \\
\text { DEPRE }\end{array}$ & $\begin{array}{c}\text { BOOK } \\
\text { VALUE }\end{array}$ \\
\hline 1 & 214.450 .000 & 26.806 .250 & 26.806 .250 & 187.643 .750 \\
\hline 2 & 214.450 .000 & 26.806 .250 & 53.612 .500 & 160.837 .500 \\
\hline 3 & 214.450 .000 & 26.806 .250 & 80.418 .750 & 134.031 .250 \\
\hline 4 & 214.450 .000 & 26.806 .250 & 107.225 .000 & 107.225 .000 \\
\hline 5 & 214.450 .000 & 26.806 .250 & 134.031 .250 & 80.418 .750 \\
\hline 6 & 214.450 .000 & 26.806 .250 & 160.837 .500 & 53.612 .500 \\
\hline 7 & 214.450 .000 & 26.806 .250 & 187.643 .750 & 26.806 .250 \\
\hline 8 & 214.450 .000 & 26.806 .250 & 214.450 .000 & - \\
\hline
\end{tabular}

Tabel 4.2

Tabel Penyusutan Vehicles PT Chandra Sakti Utama Leasing

Penyusutan Mobil Toyota TOYOTA Rush S A/T TRD setiap tahun adalah Rp 26.806.250,-. PT Chandra Sakti Utama Leasing membukukan perhitungan penyusutan setiap bulan, maka di akhir bulan PT Chandra Sakti Utama Leasing 
mencatat penyusutan Aset Tetap (Mobil

Toyota TOYOTA Rush S A/T TRD) senilai:

Penyusutan Tiap Tahun $: \operatorname{Rp} 26.806 .250,-/ 12=$ Rp 2.233.8

Penyusutan 1 Unit Laptop HP Pavilion :

\begin{tabular}{|c|c|l|l|l|}
\hline TH & HP & \multicolumn{1}{|c|}{ DEPRE } & $\begin{array}{c}\text { ACC. } \\
\text { DEPRE }\end{array}$ & \multicolumn{1}{|c|}{$\begin{array}{c}\text { BOOK } \\
\text { VALUE }\end{array}$} \\
\hline 1 & 7.300 .000 & 1.095 .000 & 1.095 .000 & 6.205 .000 \\
\hline 2 & 7.300 .000 & 1.460 .000 & 1.460 .000 & 4.745 .000 \\
\hline 3 & 7.300 .000 & 1.460 .000 & 1.460 .000 & 3.285 .000 \\
\hline 4 & 7.300 .000 & 1.460 .000 & 1.460 .000 & 1.825 .000 \\
\hline 5 & 7.300 .000 & 1.460 .000 & 1.460 .000 & 365.000 \\
\hline 6 & 7.300 .000 & 365.000 & 365.000 & - \\
\hline
\end{tabular}

Tabel 4.3

Tabel Penyusutan Office Equipment

PT Chandra Sakti Utama Leasing

Penyusutan Fit Out CSUL ABU Jakarta

Barat (ABU 2) :

\begin{tabular}{|c|c|c|c|c|}
\hline TH & HP & DEPRE & $\begin{array}{c}\text { ACC. } \\
\text { DEPRE }\end{array}$ & $\begin{array}{c}\text { BOOK } \\
\text { VALUE }\end{array}$ \\
\hline 1 & 209.880 .480 & 1.749 .004 & 1.749 .004 & 208.131 .476 \\
\hline 2 & 209.880 .480 & 20.988 .048 & 20.988 .048 & 187.143 .428 \\
\hline 3 & 209.880 .480 & 20.988 .048 & 20.988 .048 & 166.155 .380 \\
\hline 4 & 209.880 .480 & 20.988 .048 & 20.988 .048 & 145.167 .332 \\
\hline 5 & 209.880 .480 & 20.988 .048 & 20.988 .048 & 124.179 .284 \\
\hline 6 & 209.880 .480 & 20.988 .048 & 20.988 .048 & 103.191 .236 \\
\hline 7 & 209.880 .480 & 20.988 .048 & 20.988 .048 & 82.203 .188 \\
\hline 8 & 209.880 .480 & 20.988 .048 & 20.988 .048 & 61.215 .140 \\
\hline 9 & 209.880 .480 & 20.988 .048 & 20.988 .048 & 40.227 .092 \\
\hline 10 & 209.880 .480 & 20.988 .048 & 20.988 .048 & 19.239 .044 \\
\hline 11 & 209.880 .480 & 19.239 .044 & 19.239 .044 & - \\
\hline
\end{tabular}

Tabel 4.4

Tabel Penyusutan Office Fixture \& Fitting

PT Chandra Sakti Utama Leasing

Cara Pencatatan dan Penyajian Laporan Aset Tetap Pada PT Chandra Sakti Utama

\section{Leasing.}

Pencatatan aset tetap yang dilakukan

PT Chandra Sakti Utama Leasing sebagai berikut :

Pencatatan Berdasarkan Accounting Finance

Pembayaran dilakukan oleh PT Chandra Sakti Utama Leasing dengan cara transfer melalui e-Banking Mandiri, pembayaran dilakukan setelah barang diterima dan invoice berada di departemen finance. Setelah finance menerima invoice kendaraan baru tanggal 28 November 2014 berdasarkan pembelian mobil Toyota TOYOTA Rush $\mathrm{S}$ A/T TRD dari PT Chandra Sakti Utama Leasing harga perolehannya sebagai berikut :

\begin{tabular}{|l|lr|}
\hline Harga Beli Kendaraan & $\mathrm{Rp}$ & 189.272 .728 \\
\hline Discount & $\mathrm{Rp}$ & $(22.727 .273$ \\
\hline Dasar Pengenaan Pajak & $\mathrm{Rp}$ & 166.545 .455 \\
\hline Pajak Pertambahan Nilai & $\mathrm{Rp}$ & 16.654 .545 \\
\hline Biaya Adm Surat Kendaraan & $\mathrm{Rp}$ & 31.250 .000 \\
\hline Total ( IDR ) & $\mathbf{R p}$ & $\mathbf{2 1 4 . 4 5 0 . 0 0 0}$ \\
\hline
\end{tabular}

maka pencatatannya adalah sebagai berikut :

\begin{tabular}{|c|c|c|c|}
\hline COA & Description & Debit & Kredit \\
\hline 311000 & Fixed Asset Motor Vehicles & Rp214.450.000 & \\
\hline 121313 & Mandiri Operational & & Rp 214.450.000 \\
\hline
\end{tabular}

Aset tetap ini akan mengalami penyusutan. Pada setiap akhir bulan accounting akan mencatat penyusutan tersebut. PT Chandra Sakti Utama Leasing mengakui umur manfaat untuk kendaraan mobil adalah 8 tahun, dengan asumsi tidak ada nilai sisa. Maka setiap bulan accounting akan mencatat sebagai berikut :

Penyusutan per tahun $R p$ 26.806.250,-/12 = Rp 2.233.854,-

\begin{tabular}{|c|c|c|c|}
\hline COA & Description & Debit & Kredit \\
\hline 852100 & Depr. Fixed Asset Motor Vehicles & Rp 2.233 .854 & \\
\hline 351000 & Accum Depre. Motor Vehicles & & Rp 2.233 .854 \\
\hline
\end{tabular}

\section{KESIMPULAN}

Berdasarkan penelitian yang telah penulis lakukan dan akan bermanfaat bagi PT Chandra Sakti Utama Leasing dalam 
Metode Penerapan Aset Tetap yang telah dijalankan selama ini.

Perhitungan harga perolehan aset tetap pada PT Chandra Sakti Utama Leasing adalah semua biaya-biaya yang berhubungan langsung dengan aset tetap tersebut sampai aset dapat digunakan. Perhitungan penyusutan aset tetap pada PT Chandra Sakti Utama Leasing menggunakan metode garis lurus, dicatat setiap akhir bulan menjelang closing akhir bulan yang di input dalam sistem EGL Confins dan sudah mengacu dalam PSAK No.16 tentang Aset Tetap. Pengelompokkan umur ekonomis aset tetap pada PT Chandra Sakti Utama Leasing sudah ditentukan oleh divisi accounting dan managemen dengan melalui beberapa revisi dan akhirnya disahkan. Besarnya biaya penyusutan aset tetap pada PT Chandra Sakti Utama Leasing adalah sama disetiap bulannya, dengan asumsi tidak ada nilai sisa pada aset tetap pada akhir umur ekonomis. Pencatatan dilakukan apabila pada saat barang telah diterima maka divisi accounting akan mencatat dan menjurnal kedalam sistem confins setelah itu di filling berdasarkan tanggal pembelian.

\section{SARAN}

Berdasarkan kesimpulan diatas serta memperhatikan hasil pengamatan dan pembahasan, dibawah ini saran yang dapat penulis berikan sebatas kemampuan yang penulis miliki, mungkin bermanfaat untuk perusahaan guna meningkatkan efesiensi dan efektivitas dalam kegiatan operasional perusahaan antara lain :

1. Perhitungan penyusutan Aset Tetap pada PT Chandra Sakti Utama Leasing sudah sesuai dengan aturan akuntansi yang berlaku yaitu Metode Garis Lurus (Straight Line Method). Pada saat aset tersebut diperoleh maka langsung penyusutan asetnya dicatat pada akhir bulan, apabila pembelian aset tetap tersebut diatas tanggal 15 maka akan disusutkan bulan berikutnya. Karena pencatatan penyusutan sudah baik, maka penulis sarankan sebaiknya perhitungan penyusutan Aset Tetap pada PT Chandra Sakti Utama Leasing dipertahankan.

2. Pengelompokkan umur ekonomis Aset Tetap pada PT Chandra Sakti Utama Leasing masih berdasarkan kebijakan perusahaan dan nilai residunya o (tidak ada). Penulis sarankan sebaiknya ada nilai residu setelah akhir umur ekonomis.

3. Pencatatan dan penyajian laporan aset tetap di neraca pada PT Chandra Sakti Utama Leasing sudah sesuai peraturan perusahaan dan sudah mengacu ke aturan akuntansi yang berlaku. Penulis sarankan agar penyajian laporan keuangan sebaiknya dipertahankan.

\section{DAFTAR PUSTAKA}

Dewan Standar Akuntansi Indonesia, Explosure Draft. Jakarta: Ikatan Akuntansi Indonesia, ED PSAK 16 Revisi 2011 
Jusup, Al Haryono. Dasar-Dasar Akuntansi.

Yogyakarta: Sekolah Tinggi Ilmu

Ekonomi YKPN, Cetakan kedua 2014

Manurung, Elvy Maria. Akuntansi Dasar. Erlangga, 2011

Nayla, P Akifa. Akuntansi Jasa Dagang dan Perbankan. Yogyakarta: Laksana, Cetakan Pertama 2014

Nuh, Mumammad., dan Hamizar. Intermediate Accounting. Jakarta: Lentera Ilmu Cendikia, Edisi Revisi 2011

Rudianto, Pengantar Akuntansi. Jakarta: Erlangga, 2012 